\title{
Effect of row spacing and nitrogen levels on the growth and yield of tomato under walk-in polythene tunnel condition
}

Anwar Rashid ${ }^{1 *}$, AbdurRab ${ }^{1}$, Haji Mohammad ${ }^{2}$, Jawad Ali ${ }^{1}$, Muhammad Shahab $^{1}$, Abbas Jamal ${ }^{1}$, Ali Rehman ${ }^{1}$ and Mohammad Ali ${ }^{1}$

1. Department of Horticulture, University of Agriculture Peshawar - Pakistan

2. Agriculture Extension Department Malakand- Pakistan

*Corresponding author's email: anwarrashid26@gmail.com

Citation

Anwar Rashid, AbdurRab, Haji Mohammad, Jawad Ali, Muhammad Shahab, Abbas Jamal, Ali Rehman and Mohammad Ali. Effect of row spacing and nitrogen levels on the growth \& yield of tomato under walk-in polythene tunnel condition. Pure and Applied Biology. Vol. 5, Issue 3, pp426-438. http://dx.doi.org/10.19045/bspab.2016.50055

\begin{tabular}{llll}
\hline \hline Received: 18/02/2016 & Revised: 28/04/2016 & Accepted: 04/05/2016 & Online First: 28/05/2016
\end{tabular}

\section{Abstract}

To estimate the "Effect of row spacing and nitrogen levels on the growth and yield of tomato under walk-in polythene tunnel condition" an experiment was conducted at Sakhakot in collaboration with Agriculture Extension Department Dargai Malakand Agency, Khyber Pakhtunkhwa Pakistan in the year 2011-12 to find out optimum row spacing for obtaining maximum yield of tomato under walk-in polythene tunnel condition and optimize the nitrogen level for higher tomato production. Randomized Complete Block Design (RCBD) with split plot arrangement was used in the experiment, treatments were replicated three times. There were two factors i.e. different row spacing $(60,90,120 \mathrm{~cm})$ and nitrogen levels $\left(0,60,100,140 \mathrm{~kg} \mathrm{ha}^{-1}\right)$. Tomato cultivar "Sahil" was used for the experiment. More days to flowering (62.93), days to fruiting (85.44), plant height $(264.73 \mathrm{~cm})$ and number of branches $(58.89)$ was obtained when nitrogen was applied at $140 \mathrm{~kg}$ $\mathrm{ha}^{-1}$, while maximum number of fruits $\mathrm{kg}^{-1}(12.89)$ was recorded in control plots. The maximum number of fruits plant ${ }^{-1}(61.56)$, average fruit weight plant ${ }^{-1}(3.19 \mathrm{~kg})$, fruit weight picking ${ }^{-1}$ plot $^{-1}$ $(17.78 \mathrm{~kg})$ and yield $\left(28.33\right.$ tones $\left.\mathrm{ha}^{-1}\right)$ were obtained when nitrogen was applied at $100 \mathrm{~kg} \mathrm{ha}^{-}$ ${ }^{1}$.Similarly in case of row spacing, higher days to flowering (52.03), days to fruiting (81.08), plant height $(261.23 \mathrm{~cm})$ and number of branches $(58.10)$ was obtained when plants were row spaced at $120 \mathrm{~cm}$. More number of fruits $\mathrm{kg}^{-1}$ (11.58) was recorded from the plot, having $60 \mathrm{~cm}$ row spacing. The maximum number of fruits plant ${ }^{-1}(58.03)$, average fruit weight per plant $(2.92 \mathrm{~kg})$, fruit weight picking ${ }^{-1}$ plot $^{-1}(16.89 \mathrm{~kg})$ and yield $\left(27.96\right.$ tones $\left.\mathrm{ha}^{-1}\right)$ were produced by the plots having $90 \mathrm{~cm}$ row spacing. Thus, it is concluded that Sahil cultivar treated with $100 \mathrm{~kg} \mathrm{~N} \mathrm{ha}^{-1}$ row spaced at $90 \mathrm{~cm}$ must be used in Malakand for best tomato production.

Keywords: Tomato (Lycoperesicum esculentum); Row spacing; Nitrogen levels; Plant height; Tomato production

\section{Introduction}

The botanical name of tomato is (Lycopersicon esculentum), belongs to the family Solanaceae. The Lycoperesicum genus an annual and short lived perennial herbaceous plant. Tomato is a warm season 
crop which is resistant to heat and drought and grown on many type of soil and climatic conditions [1].Tomato is native to Peru and Mexico and the indians grown it about 500 B.C. [2] Tomato is an important vegetable crop in Pakistan and grown an area of 28,880 ha which produced 3,13072 metric tons of tomato. Tomato is rich in vitamin $\mathrm{A}, \mathrm{B}, \mathrm{C}$, minerals, iron, lime and phosphorous. This fruit vegetable is popular for its nutritional value and diversified use like salad, juice, sauce etc. It contains $1.98 \mathrm{~g}$ protein, $320 \mathrm{IU}$ vitamin-A, $1.8 \mathrm{mg}$ iron and $31 \mathrm{mg}$ vitamin-C in $100 \mathrm{~g}$ edible tomato [3].

Tomato ranks second among vegetables next only to potato in area andproduction. It occupies a distinct place in the realm of vegetables because of its high nutritivevalue and large scale utilization. The arrays of processed products include juice, ketchup,sauce, paste, puree and whole canned fruits are the main constituents of 'Pizzas'.Tomato is being grown worldwide with USA, Italy, China, India, Spain, Brazil, Egypt, Mexico, Turkey and Iran as leading countries [4]. Every year tomato is grown on an area of 24,144 hectares in Pakistan, with the production of 275241 tons. In Khyber Pakhtunkhwa it is grown on area of 4230 hectares and it's per annum production is 51,062 tons. In Peshawar, tomato is cultivated on 944 acres area which produces 2.978 tons of tomato. In the last 17 years its area has been increased up to 56\% in Pakistan [4].

Studies revealed that a vegetable lowers many chronicle diseases due to high level of phytochemicals. Fraser\&Gester[5]found increasing intake of tomatoes decreased cancer risk. Tomato has naturally occurring antioxidant such as 'Lycopene' a major carotenoid which plays an important role in scavenging free radicals and protect from heart diseases, arthritis and aging process [68] in the years (2000) and (1996) respectively, evaluated NP fertilizers rates highly influenced the fruit yield in tomato. Sharma et al. [9] also found that amount of NP fertilizers rates applied affect the average fruit weight of tomato. Thus, higher fruit yields of tomato can be obtained by applying optimum amount of NP fertilizers [10].

Tomato crop requires balance fertilizer and water for high yields. Nitrogen is the most responsible element for limiting crop growth, especially on low organic matter and coarse-textured soil.The tomato yield is directly or indirectly affected by the fruit weight, the number of fruits per plant, weight of fruits per plant and vigor as well as the size of the fruits and these are the most important morphological and quantitative traits of the tomato fruit. The genetic factors that influence not only the mentioned traits but also other quantitative traits in tomato fruits which are also under the influence of environmental factors, crop density, growing practices, mineral nutrition, soil properties, and their interaction also [10 - 13]

Optimum plant spacing is very important for higher productivity of tomato. Plant spacing significantly affected fruit yield in both processing and fresh market tomatoes. Similarly, Aggrey et al [14] also stated that spacing influenced tomato yield parameters. A walk-in polythene tunnel has been defined as "a portable walk-in, greenhouse like structure without a permanent electrically powered heating or ventilation system, covered with one layer of plastic, and sited on field soil. Walk-in polythene tunnel is a permanent greenhouse like structure having the height of 7-9 feet. Walk-in tunnel cannot protect crops from temperature to the same degree as heat equipped green houses, however they are much less expensive to build and operate. Walk-in tunnels mostly used throughout the Asia, Southern Europe and Middle East for vegetable production [15]. Several researchers have reported the use of row covers and plastic tunnels over the crop row for temperature enhancement, 
greater moisture retention, elimination of insects, and reduction in plant desiccation [16 \&17]. With the passage of time and development of new technologies enhanced fabric characteristics and designs, polypropylene and polyester fabrics used in agriculture flourished plant growth due to high moisture and temperature, exclusion of harmful insects feeding on the vegetable crop and reduction in water stress from wind. In Northern and Eastern United States use of high polythene tunnels (a moveable walk-in, structure like greenhouse with no electrically powered ventilation or heating, which is covered with 6-mil single layer polyethylene) has increased production time between 3 to 12 weeks of vegetables [15].Keeping in view the importance of tomato the research was conducting with the objective to investigate an optimum row spacing for obtaining maximum yield of tomato under walk-in polythene tunnel condition and to explore an optimum nitrogen level for higher tomato production.

\section{Materials and methods}

An experiment entitled "effect of row spacing and Nitrogen levels on the growth \& yield of tomato under walk-in polythene tunnel condition" was conducted at Sakhakot in collaboration with Agriculture Extension Department Dargai Malakand Agency, Table 1. Soil Analysis of the experimental field.

\begin{tabular}{|c|c|c|c|c|c|}
\hline Determination & Nitrogen $(\%)$ & Lime $(\%)$ & $\mathrm{pH}$ & $\mathrm{EC} \mathrm{dsm}^{-1}$ & Texture \\
\hline Quality & 0.603 & 11.4 & 8.3 & 2.31 & Sandy clay loam \\
\hline
\end{tabular}

\section{Transplantation and nursery raising of seedlings}

Tomato seeds of cultivar (Sahil) used for research were brought from the local from local market in Malakand and sown in low polythene tunnel on 15 th October. The seeds were watered after sowing. Those seedlings which were of equal height and vigor were transplanted in the walk-in polythene tunnel
Pakistan during 2011-12. RCBD (split plot arrangement) was used for the experiment. Row spacing and different levels of nitrogen were the two factors, Row spacing was assigned to main plots and sub plots were allotted to Nitrogen levels. There were three replications of total twelve treatments.

\section{Soil preparation}

Soil inside the tunnel was thoroughly ploughed and leveled. Soil was mixed up with well rotten FYM. Proper height of ridges was managed manually. According to the field layout the plots were provided with four different doses of nitrogen and three different row spacing. Before transplantation of seedling recommended dose of $\mathrm{P}$ and $\mathrm{K}$ was applied to soil. Source of nitrogen used in the experiment was Urea (containing $46 \%$ nitrogen). Whereas nitrogen was applied to the soil in split doses. First dose was supplied at transplantation time and other before flowering at ten days interval after transplantation. Potassium sulphate (containing $50 \%$ of potash) was used as a source of potassium while single super phosphate (containing 18\% of phosphorous) was used for phosphorus. Before the application of other fertilizer, at depth of 15 $\mathrm{cm}$ to $30 \mathrm{~cm}$, the soil samples were randomly collected from the experimental field and analyzed and analysis is shown in Table1. 


\section{Factor A, Row Factor B, Nitrogen spacing levels(sub plot) (main plot)

$$
\begin{array}{cl}
\mathrm{S}_{1}: 60 \mathrm{~cm} & \mathrm{~N}_{0}: 0 \text { (Control) } \\
\mathrm{S}_{2}: 90 \mathrm{~cm} & \mathrm{~N}_{1}: 60 \mathrm{~kg} \mathrm{ha}^{-1} \\
\mathrm{~S}_{3}: 120 \mathrm{~cm} & \mathrm{~N}_{2}: 100 \mathrm{~kg} \mathrm{ha}^{-1} \\
& \mathrm{~N}_{3}: 140 \mathrm{~kg} \mathrm{ha}^{-1}
\end{array}
$$

The data was recorded for the following parameters during the experiment.

Plant Height $(\mathrm{cm})$, The data regarding plant height was measured in centimeter by common tape from ground to terminal end of main stem.Number of branches per plant.Stems that were originated from the main stem were counted from selected plants and their mean was calculated.Days to first flowering.Data for days to flowering was collected as number of days from transplantation till the appearance of first flower. Days to first fruiting. Data for days to fruiting was collected as number of days from transplantation till fruit setting. Fruits per plant. Data for fruits per plant were collected from five randomly selected plants in sub plots and then average them.Number of fruits $\mathrm{kg}^{-1}$. Fruits $\mathrm{kg}^{-1}$ was calculated by weighing randomly selected one $\mathrm{kg}$ fruits in each treatment and then the number of fruits was counted.Weight picking ${ }^{-1}$ plot $^{-1}$.Weight picking $^{-1}$ was determined with the help of the formula:

Weight picking ${ }^{-1}$ plot $^{-1} \equiv$ Total fruit weight in each plot Total number of picking in each plot

Average fruit weight (g).Data was recorded at plant maturity by weighing all the fruits present on a five randomly chosen plants in sub-plot and average was calculated.Yield (tones ha-1)

Yield ha-1 was calculated using the following formula:

Yield ha $^{-1}($ tones $)=\underline{\text { Yield plot }} \underline{-1} \underline{(\text { tones }) \times 10000 \mathrm{~m}^{2}}$

Plot area $\left(\mathrm{m}^{2}\right)$

\section{Statistical procedure}

The data collected on different parameters was subjected to analysis of variance (ANOVA) technology to observe the difference, between different treatments as well as their interactions. In case where the difference was significant the mean was further assist for differences through least significant difference (LSD) test. Statistical computer software, MSTATC (Michigan state university, USA), was applied for computing both ANOVA and LSD [18].

\section{Results and discussion Plant height (cm)}

The data regarding plant height is presented in Table-2. The statistical analysis clearly showed that plant height was significantly influenced by nitrogen levels and the interaction between row spacing and nitrogen levels, while row spacing had no significant effect on plant height of tomato. The tallest $(261.23 \mathrm{~cm})$ plants were observed in the plots having $120 \mathrm{~cm}$ row spacing, while the shortest plants $(253.28 \mathrm{~cm})$ were observed by the plots having $90 \mathrm{~cm}$ row spacing. The tallest $(264.73 \mathrm{~cm})$ plants were observed in the plots fertilized with $140 \mathrm{~kg} \mathrm{ha}^{-1}$ which was at par with 100 and $60 \mathrm{~kg} \mathrm{~N} \mathrm{ha}^{-1}(260.13$ and 260.02 respectively). While shortest plants $(244.58 \mathrm{~cm})$ were observed by plots untreated with nitrogen. The maximum plant height (276.53) was observed in plants fertilized with $140 \mathrm{~kg} \mathrm{~N} \mathrm{ha}^{-1}$ at row spacing $120 \mathrm{~cm}$ while the least plant height (239.33) was observed in plants untreated with nitrogen at row spacing $90 \mathrm{~cm}$.

Maximum plant height recorded in plots fertilized with $140 \mathrm{~kg} \mathrm{~N}^{-1}$ might be due to the reason that nitrogen increased vegetative growth and endogenous auxin which promote gibberellins activity and increased plant height. These results confirmed the works of Raja gopal et al. [19] who stated that nitrogen deficient plants have less auxin and gibberellins activity and higher level of growth inhibitors. These results confirmed 
the works of Gaffer \& Razzaque et al. [20] who found a significant increase in plant height.

Table 2. Impact of row spacing and nitrogen $(\mathrm{N})$ on tomato plant height $(\mathrm{cm})$

\begin{tabular}{c|ccc|c}
\hline \multirow{2}{*}{$\mathbf{N}\left(\mathbf{k g ~ h a}^{\mathbf{1}}\right)$} & \multicolumn{3}{|c|}{ Row spacing $\mathbf{( c m )}$} & \multirow{2}{*}{ Mean } \\
\cline { 2 - 4 } & 60 & 90 & 120 & $244.58 \mathrm{~b}$ \\
0 & 249.13 & 239.33 & 245.27 & $260.02 \mathrm{a}$ \\
60 & 251.87 & 262.73 & 265.47 & $260.13 \mathrm{a}$ \\
100 & 263.07 & 259.67 & 257.67 & $264.73 \mathrm{a}$ \\
\hline 140 & 266.27 & 251.40 & 276.53 & \\
\hline Mean & $\mathbf{2 5 7 . 5 8}$ & $\mathbf{2 5 3 . 2 8}$ & $\mathbf{2 6 1 . 2 3}$ & \\
\hline
\end{tabular}

LSD for nitrogen at $5 \%$ level of significance $=7.838$

LSD for interaction at $5 \%$ level of significance $=13.577$

Means followed by the same letter(s) do not differ significantly from one another at 5\% probability level, using LSD test.

\section{Number of branches Plant ${ }^{-1}$}

The data regarding No of branches per plant is presented in Table-3. The statistical analysis of the data revealed that row spacing, nitrogen levels and their interaction significantly influenced number of branches (Table-3). Application of $140 \mathrm{~kg} \mathrm{~N} \mathrm{ha-}$ ${ }^{1}$ produced more number of branches $(60.00)$, followed by $100 \mathrm{~kg} \mathrm{~N} \mathrm{ha}^{-1}(55.86)$ and $60 \mathrm{~kg}$ $\mathrm{N} \mathrm{ha}^{-1}$ (55.22) which were at par with each other, while control plants produced less number of branches (48.63). More branches (57.77) were produced by plot having $120 \mathrm{~cm}$ row spacing, which was at par with row spacing at $90 \mathrm{~cm}$ whereas, less number of branches were recorded (51.10) for $60 \mathrm{~cm}$ row spacing plot. Thus, high row spacing plots have high potential for more number of branches as compare to the other plots. Interaction between row spacing and nitrogen levels was also highly significant. More number of branches plant ${ }^{-1}$ (62.00) was observed in plants at $140 \mathrm{~kg} \mathrm{~N} \mathrm{ha}^{-1}$ and row spaced at $120 \mathrm{~cm}$ while less number of branches plant ${ }^{-1}$ (37.89) was observed in plants at row spacing $60 \mathrm{~cm}$ in control plots. More number of branches were at $120 \mathrm{~cm}$ row spacing and higher nitrogen application might be due to the reason that there was less competition among plants for nutrients (nitrogen), light, water and space which enhanced vegetative growth of the plants and hence showed good performance regarding more number of branches [21]. Prabhakar \& Naik et al. [22] also recorded these findings" which observed more number of branches plant $^{-1}$ with the increasing nitrogen levels. Increasing the application of nitrogen increased the number of branches were recorded by the Shukla et al. [23]. Olasantan [24] as they noticed that the nitrogen application is directly proportional to the number of branches.

\section{Days to flowering}

Table-4 presents the data regarding row spacing and nitrogen levels for days to flowering. ANOVA shows that nitrogen levels and row spacing significantly affect days to flowering. Maximum days to flowering (52.03) were counted from plants row spaced at $120 \mathrm{~cm}$ which was at par with plants row spaced at $90 \mathrm{~cm}$ (49.36) whereas, minimum days to flowering (44.39) were counted from plot having $60 \mathrm{~cm}$ row spacing. Application of $140 \mathrm{~kg} \mathrm{~N}^{-1}$ delayed (62.93 days) flowering, which significantly varied from the rest of the treatments followed by 100 and $60 \mathrm{~kg} \mathrm{~N} \mathrm{ha}^{-1}$ which were 48.59 and 46.74 respectively. While early flowering (36.11 days) was recorded in untreated plants 
with nitrogen. Thus, application of the nitrogen delayed flowering. The interaction between row spacing and nitrogen levels was highly significant. Maximum days to flowering (66.22) were recorded in plants fertilized with $140 \mathrm{~kg} \mathrm{~N} \mathrm{ha}^{-1}$ and at row spacing $120 \mathrm{~cm}$ while the less number of days to flowering (34.67) were observed in plants untreated with nitrogen at row spacing $60 \mathrm{~cm}$. Maximum number of days to flowering recorded at $120 \mathrm{~cm}$ row spacing might be due to the reason that there was less competition among plants for nutrients, light and water uptakes which enhanced vegetative period of the plants and delayed flowering. The most sensitive character to nitrogen fertilizer is perhaps flowering, which enhanced vegetative growth and delayed flowering. These results also confirmed the work of Kagya \& Norman [25] who stated that nitrogen increases days to flowering. Zekri \& Obreza [26] stated that as nitrogen is the most responsible constituent for vegetative growth, flower and fruit formation so in case of less availability of nitrogen would lower plant vigor which caused early flowering. In fact Biological molecules is mainly composed of nitrogen hence high nitrogen levels increases plant vigor which ultimately delayed flowering by enhancing vegetative period [27]. High fertilizer level increased days to flowering [28].

Table 3.Impact of row spacing and nitrogen $(N)$ on number of branches of tomato

\begin{tabular}{|c|c|c|c|c|}
\hline \multirow{2}{*}{ N (kg ha ${ }^{-}$} & \multicolumn{3}{|c|}{ Row spacing $(\mathrm{cm})$} & \multirow[b]{2}{*}{ Mean } \\
\hline & 60 & 90 & 120 & \\
\hline 0 & 37.89 & 49.33 & 58.67 & $48.63 c$ \\
\hline 60 & 52.67 & 58.00 & 55.00 & $55.22 b$ \\
\hline 100 & 54.52 & 57.64 & 55.41 & $55.86 \mathrm{~b}$ \\
\hline 140 & 59.33 & 58.67 & 62.00 & $60.00 \mathrm{a}$ \\
\hline Mean & $51.10 \mathrm{~b}$ & $55.91 \mathrm{a}$ & $57.77 \mathrm{a}$ & \\
\hline \multicolumn{5}{|c|}{$\begin{array}{l}\text { LSD for } \mathrm{S} x \mathrm{~N} \\
\text { Means followed by the same letter(s) do not differ significantly from one another at } 5 \% \text { probability level, using LSI } \\
\text { test. } \\
\text { Table 4. Impact of row spacing and nitrogen }(\mathbf{N}) \text { on days to flowering of tomato }\end{array}$} \\
\hline \multirow{2}{*}{$N\left(\mathrm{~kg} \mathrm{ha}^{-1}\right)$} & \multicolumn{3}{|c|}{ Row spacing (cm) } & \multirow[b]{2}{*}{ Mean } \\
\hline & 60 & 90 & 120 & \\
\hline 0 & 34.67 & 36.56 & 37.11 & $36.11 \mathrm{c}$ \\
\hline 60 & 38.33 & 51.56 & 50.33 & $46.74 b$ \\
\hline 100 & 41.33 & 50.00 & 54.44 & $48.59 \mathrm{~b}$ \\
\hline 140 & 63.22 & 59.33 & 66.22 & $62.93 \mathrm{a}$ \\
\hline Mean & $44.39 b$ & $49.36 \mathrm{a}$ & $52.03 \mathrm{a}$ & \\
\hline
\end{tabular}

LSD for Row spacing $=3.8003$

LSD for Nitrogen $=3.2534$

LSD for $\mathrm{S} \times \mathrm{N}=5.6351$

Means followed by the same letter(s) do not differ significantly from one another at 5\% probability level, using LSD test 


\section{Days to fruiting}

Means of Row spacing and nitrogen levels for days to fruiting are given in Table-5. The statistical analysis of the data revealed that row spacing, nitrogen levels and their interaction significantly influenced days to fruiting. Control plot gave early fruiting (67.44 days), while application of $140 \mathrm{~kg} \mathrm{~N}$ $\mathrm{ha}^{-1}$ delayed (85.44 days) fruiting. The collected data indicated that tomato performance was highly changed by nitrogen application. Vegetative growth increased by nitrogen, which delayed fruiting by delaying flowering. Regarding row spacing, plots having row spacing of $60 \mathrm{~cm}$ gave early fruiting (75.83 days) which was significantly different from the rest of row spacing, while plots having row spacing of $120 \mathrm{~cm}$ were late fruiting (81.08 days). Maximum days to fruiting (90.67) were recorded in plants fertilized with $140 \mathrm{~kg} \mathrm{~N} \mathrm{ha}^{-1}$ and at row spacing $120 \mathrm{~cm}$ while the less number of days to fruiting (64.00) were observed in plants untreated with nitrogen at row spacing 120 $\mathrm{cm}$.

Days to fruiting was highly affected by the application of different nitrogen levels and row spacing. Maximum number of days to fruiting recorded at $120 \mathrm{~cm}$ row spacing might be due to the reason that there was less competition among plants for nutrients, light and water uptakes which enhanced vegetative period of the plants and delayed flowering. In addition the energy required for flower inducing was utilized by the excessive vegetative growth of the plant in cell division and cell elongation so, plants took more time in order to recover the required energy for flower inducing. These results supported the work of Kagya\& Norman [25] who showed that nitrogen is responsible for delaying fruiting. Sainjuet al [29] concluded that because of the limited cropping area the most desirable character for breeding purposes is first fruiting. Fruit setting and maturation can be delayed by excessive vegetative growth stimulated by high nitrogen level.

\section{Number of fruits plant ${ }^{-1}$}

The data regarding row spacing and nitrogen levels for number of fruits per plant is given in Table-6. The statistical analysis of the data revealed that row spacing and nitrogen levels significantly influenced number of fruit plant- ${ }^{1}$. Interaction was recorded nonsignificantly. More number of fruits plant ${ }^{-1}$ (58.03) was produced by plots having $90 \mathrm{~cm}$ row spacing whereas; minimum number of fruits (51.11) was produced by plots having $60 \mathrm{~cm}$ row spacing. Application of $100 \mathrm{~kg} \mathrm{~N}$ $\mathrm{ha}^{-1}$, gave the highest number of fruit plant ${ }^{-1}$ (61.56) with respect to other treatments it was statistically not same. Control treatment gave the minimum number of fruits per plant (47.48).

More number of fruits plant ${ }^{-1}$ recorded at 90 $\mathrm{cm}$ row spacing might be due to the maximum uptake of nutrients as there was less competition among plants, these maximum nutrients positively influenced vegetative growth and photosynthates production ultimately resulting increased store food. These stored foods in turn increase fruits per plant. Nitrogen at the rate of100 kg ha ${ }^{-1}$ increases number of fruits plant $^{-1}[27]$.Maximum fruits per plant were obtained when nitrogen at the rate of $120 \mathrm{~kg}$ $\mathrm{ha}^{-1}$ was applied [9].Increased number of fruits plant ${ }^{-1}$ was observed by $120 \mathrm{~kg} \mathrm{~N} \mathrm{ha}^{-1}$. Further application of $\mathrm{N}$ decreased fruits plant $^{-1}$. Similarly Banerjee et al and Haque et al. $[30,27]$ found that $\mathrm{N}$ application of 125 $\mathrm{kg} \mathrm{ha}^{-1}$ gave highest fruits per plant. Kirimi et al [31] observed that plots without nitrogen and those fertilized with the highest nitrogen level have more number of fruits plant ${ }^{-1}$ and those fertilized with optimum level of nitrogen have less number of fruits plant $^{-1}$ with large. 
Table 5.Impact of row spacing and nitrogen (N) on days to fruiting of tomato

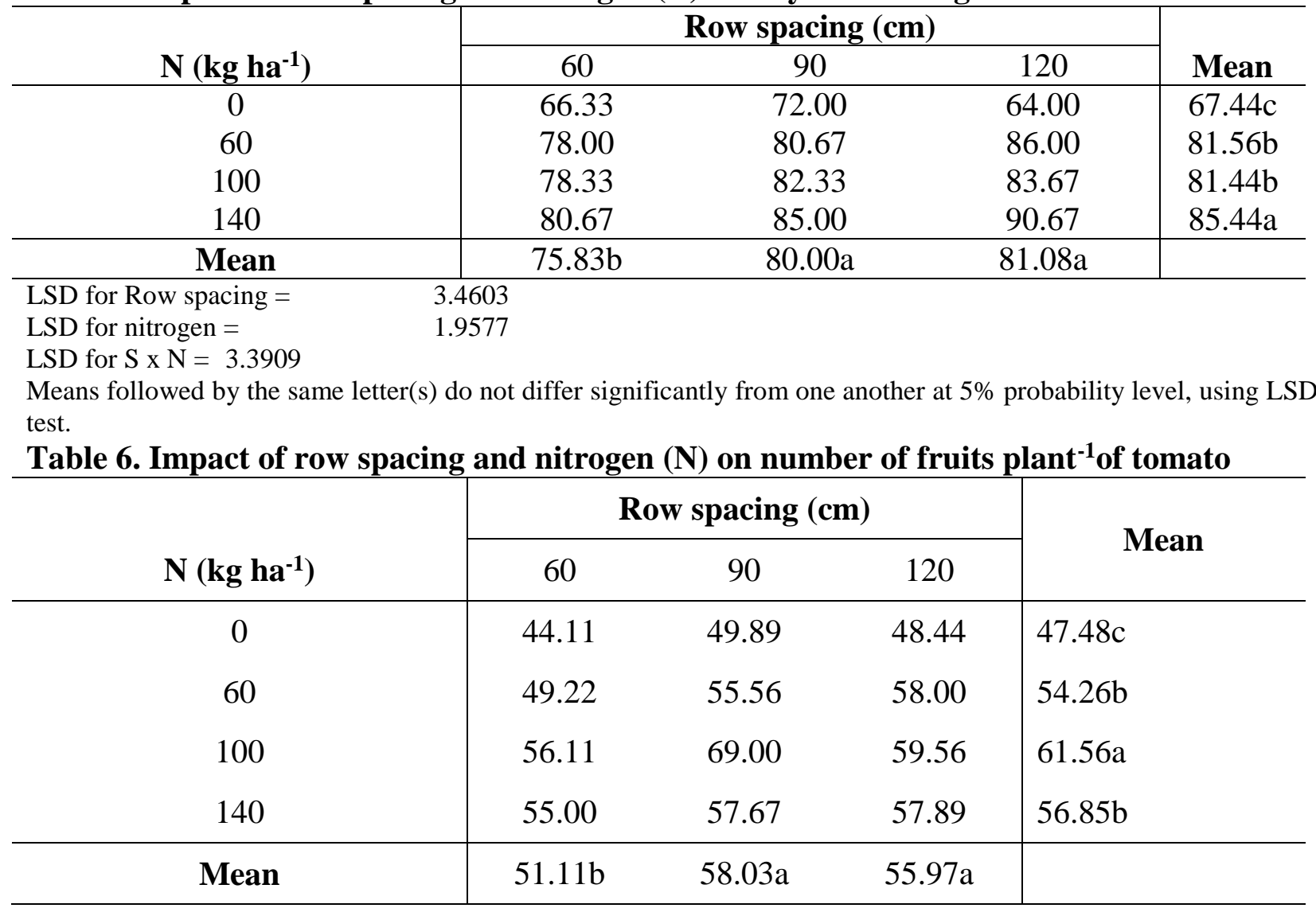

LSD for Rowspacing $=3.902$

LSD for nitrogen $=3.160$

Means followed by the same letter(s) do not differ significantly from one another at 5\% probability level, using LSD test.

\section{Number of fruits $\mathrm{Kg}^{-1}$}

The data regarding row spacing and nitrogen levels for number of fruits $\mathrm{Kg}^{1}$ is given in Table-7. The statistical analysis of the data revealed that row spacing, nitrogen levels and their interaction significantly influenced number of fruits $\mathrm{kg}^{-1}$. Maximum number of fruitskg ${ }^{-1}$ (11.58) was produced by plots having $60 \mathrm{~cm}$ row spacing whereas; minimum number of fruits $\mathrm{kg}^{-1}$ (9.86) was produced by plots having $90 \mathrm{~cm}$ row spacing which was statistically indifferent with 120 $\mathrm{cm}$ row spacing (10.22). Nitrogen control treatment gave highest number of fruits plant ${ }^{-}$ ${ }^{1}$ (12.89), which was statistically different from other treatments, followed by plants fertilized with $140 \mathrm{~kg} \mathrm{~N}^{-1}(10.33)$. The lowest fruits $\mathrm{kg}^{-1}(9.11)$ was produced by 100 $\mathrm{kg} \mathrm{N} \mathrm{ha}{ }^{-1}$. Maximum number of fruits $\mathrm{kg}$ ${ }^{1}(15.33)$ were recorded in plants untreated with nitrogen and at row spacing $60 \mathrm{~cm}$ while the less number of fruits $\mathrm{kg}^{-1}(8.67)$ were observed in plants fertilized with $100 \mathrm{~kg} \mathrm{~N}$ $\mathrm{ha}^{-1}$ at row spacing $90 \mathrm{~cm}$.

More number of fruits $\mathrm{kg}^{-1}$ recorded at minimum row spacing $(60 \mathrm{~cm})$ might be due to the minimum uptake of nutrients as there was more competition among plants and hence small size of tomato fruits were formed. Increasing nitrogen application rate increased fruit size (length, girth and weight) was recorded bySubramanianet al[32].Stunted growth and less number of fruits and size in tomato can cause by nitrogen deficiency [29].Less nitrogen concentration reduced plant growth by 
decreasing photosynthetic activity which ultimately decreased fruit size in tomato[26].Dod et al[33]investigated that $100-125 \mathrm{~kg} \mathrm{~N}^{-1}$ significantly increased fruit length in tomato.

\section{Average fruit weight plant $^{-1}$}

The data regarding row spacing and nitrogen levels for average fruit weight plant ${ }^{-1}$ is given in Table -8.Data revealed that nitrogen levels and row spacing significantly influenced fruit weight plant ${ }^{-1}$. Interaction was recorded nonsignificantly. Maximum fruit weight plant $^{-1}$ $(2.92 \mathrm{~kg}$ ) was produced by plots having 90 cm row spacing closely followed by plants row spaced at $120 \mathrm{~cm}(2.70 \mathrm{~kg})$ whereas; minimum fruit weight plant $^{-1}(2.27 \mathrm{~kg})$ was produced by plants row spaced at $60 \mathrm{~cm}$. Application of $100 \mathrm{~kg} \mathrm{~N} \mathrm{ha}^{-1}$ gave the highest fruit weight plant ${ }^{-1}$ (3.19), followed by plants treated with 140 and $60 \mathrm{~kg} \mathrm{~N}^{-1}$ (2.71 and $2.48 \mathrm{~kg}$ respectively). The lowest fruit weight plant $^{-1}(2.13 \mathrm{~kg})$ was produced by the control treatment.
More number of fruit weight plant $^{-1}$ recorded at $90 \mathrm{~cm}$ row spacing might be due to the maximum uptake of nutrients as there was less competition among plants, these maximum nutrients positively influenced vegetative growth and high photosynthetic activity production ultimately resulting increased store food. These stored foods in turn increase fruit weight of the plant. Average fruit weight plant $^{-1}$ was highly influenced by nitrogen levels and row spacing. Application of higher NP fertilizers rates gave greater average tomato fruit weight reported by Sharma et al. [9].Highest row spacing results maximum fruit weight instead of closed row spacing in tomato reported by Ali [34]. Balemi [35] stated that higher nitrogen application gave greater fruit weight per plant in tomato. In contrast row spacing had no effect on fruit weight of tomato were reported by Jia and Rashid [36, 37] stated that fertilizer rates had no effect on average fruit of tomato.

Table 7. Impact of row spacing and nitrogen $(\mathrm{N})$ on number of fruits $\mathrm{kg}^{-1} \mathrm{of}$ tomato

\begin{tabular}{c|ccc|c}
\hline \multirow{2}{*}{$\mathbf{N}\left(\mathbf{k g ~ h a}^{-\mathbf{1}}\right)$} & \multicolumn{3}{|c|}{ Row spacing (cm) } & \multirow{2}{*}{ Mean } \\
\cline { 2 - 4 } 0 & 60 & 90 & 120 & $12.89 \mathrm{a}$ \\
60 & 15.33 & 12.00 & 11.33 & $9.89 \mathrm{~b}$ \\
100 & 11.33 & 9.78 & 8.56 & $9.11 \mathrm{c}$ \\
140 & 9.33 & 8.67 & 9.33 & $10.33 \mathrm{~b}$ \\
\hline Mean & 10.33 & 9.00 & 11.67 & \\
\hline
\end{tabular}

LSD for Row spacing at $5 \%$ level of significance $=1.2340$

LSD for Nitrogen at $5 \%$ level of significance $=0.5718$

LSD for $\mathrm{S} \times \mathrm{N}$ at $5 \%$ level of significance $=0.9904$

Means followed by the same letter(s) do not differ significantly from one another at $5 \%$ probability level, using LSD test. 
Table 8. Impact of row spacing and nitrogen $(\mathrm{N})$ on average fruit weight plant $^{-1}$ of tomato

\begin{tabular}{c|ccc|c}
\hline \multirow{2}{*}{$\mathbf{N}\left(\mathbf{k g ~ h a}^{-1}\right)$} & \multicolumn{3}{|c|}{ Row spacing (cm) } & \multirow{2}{*}{ Mean } \\
\cline { 2 - 4 } & 60 & 90 & 120 & \\
\hline 0 & 1.87 & 2.38 & 2.13 & $2.13 \mathrm{c}$ \\
60 & 2.23 & 2.72 & 2.50 & $2.48 \mathrm{~b}$ \\
100 & 2.73 & 3.53 & 3.30 & $3.19 \mathrm{a}$ \\
140 & 2.23 & 3.03 & 2.85 & $2.71 \mathrm{~b}$ \\
\hline Mean & $2.27 \mathrm{~b}$ & $2.92 \mathrm{a}$ & $2.70 \mathrm{ab}$ & \\
\hline LSD for Row spacing & 0.4591 & & &
\end{tabular}

Means followed by the same letter(s) do not differ significantly from one another at $5 \%$ probability level, using LSD test.

\section{Fruit weight picking ${ }^{-1}$ plot $^{-1}$}

The data regarding row spacing and nitrogen levels for fruit weight picking ${ }^{-1}$ plant $^{-1}$ is given in Table -9.The statistical analysis of the data revealed that row spacing and nitrogen levels significantly influenced fruit weight picking ${ }^{-1}$ plant $^{-1}$ but the interaction was non-significant. Maximum fruit weight picking ${ }^{-1}$ plot $^{-1}$ (16.89) was produced by plots having $90 \mathrm{~cm}$ row spacing closely followed by row spacing at $120 \mathrm{~cm}(15.17)$ whereas; minimum fruit weight picking ${ }^{-1}$ plot $^{-1}(14.40)$ was produced by plots having $60 \mathrm{~cm}$ row spacing. Maximum fruit weight picking $^{-1}$ plot $^{-1}$ (17.78) was obtained by $100 \mathrm{~kg} \mathrm{~N} \mathrm{ha}^{-1}$. Minimum fruit weight picking ${ }^{-1}$ plot $^{-1}(13.50)$ was produced by the control treatment.

Maximum fruit weight picking ${ }^{-1}$ plot $^{-1}$ recorded at $90 \mathrm{~cm}$ row spacing might be due to the maximum uptake of nutrients as there was less competition among plants, these maximum nutrients positively influenced vegetative growth and photosynthates production ultimately resulting increased store food. These stored foods in turn increase fruit weight of the plant. Fruit weight per picking plot $^{-1}$ was highly influenced by nitrogen levels and row spacing. Balemi [35] reported that, the highest number of fruits picking ${ }^{-1}$ plot $^{-1}$ was influenced by high nitrogen and phosphorus rate.

\section{Fruit yield (ton ha-1)}

The data regarding row spacing and nitrogen levels for fruit yield is given in Table-10. The nitrogen and row spacing significantly influenced fruit yield. Interaction was recorded non- significantly. Maximum fruit yield ha- ${ }^{-1}\left(27.96\right.$ tons $\left.\mathrm{ha}^{-1}\right)$ was produced by the plots having $90 \mathrm{~cm}$ row spacing whereas; minimum yield $\mathrm{ha}^{-1}$ (25.13 tons) was produced by the plots having $120 \mathrm{~cm}$ row spacing. Highest yield (28.33 tons ha $\left.{ }^{-1}\right)$ was given by $100 \mathrm{~kg} \mathrm{~N} \mathrm{ha}{ }^{-1}$ while, the lowest (23.17 tons ha ${ }^{-1}$ ) was recorded in control plot. Maximum fruit yield recorded at $90 \mathrm{~cm}$ row spacing might be due to the maximum uptake of nutrients (nitrogen) as there was less competition among plants, these maximum nutrients (nitrogen) positively influenced vegetative growth and photosynthates production ultimately resulting increased store food. These stored foods in turn increase fruit yield. In addition, the application of high level of nitrogen enhance plant vigor by increasing photosynthetic activity in plant which ultimately results in healthy fruit formation and maximize fruit yield. Row spacing disturbs production and yield of the tomato up to the greater extent. Rashid [37] concluded that row spacing of 
the plant greatly affected the quality and production of the tomato. Tomato marketable yield was increased by the application of 120 $\mathrm{kg} \mathrm{N}$ ha $^{-1}$ [38]. Application of 120 to $125 \mathrm{~kg}$ $\mathrm{N}$ ha $^{-1}$ resulted maximum tomato yield
[30].Pandey et al. [7]found that application of $80 \mathrm{~kg} \mathrm{~N}$ ha $^{-1}$ increased fruit yield in tomato. Nitrogen is the most responsible component for the overall yield in tomato were reported by Badr\& El-Yazied [39].

\section{Table 9. Impact of row spacing and nitrogen $(\mathrm{N})$ on fruit weight picking-1 plot $^{-1}$ of tomato}

\begin{tabular}{|c|c|c|c|c|}
\hline \multirow{2}{*}{$\mathbf{N}\left(\mathbf{k g ~ h a}^{-1}\right)$} & \multicolumn{3}{|c|}{ Row spacing (cm) } & \multirow{2}{*}{ Mean } \\
\hline & 60 & 90 & 120 & \\
\hline 0 & 13.50 & 15.00 & 12.00 & $13.50 \mathrm{c}$ \\
\hline 60 & 13.67 & 16.05 & 16.00 & $15.24 b$ \\
\hline 100 & 16.00 & 20.00 & 17.33 & $17.78 \mathrm{a}$ \\
\hline 140 & 14.42 & 16.50 & 15.33 & $15.42 \mathrm{~b}$ \\
\hline Mean & $14.40 \mathrm{~b}$ & $16.89 \mathrm{a}$ & $15.17 \mathrm{ab}$ & \\
\hline LSD for Row spacing & \multicolumn{4}{|l|}{1.803} \\
\hline $\begin{array}{l}\text { LSD for nitrogen } \\
\text { Means followed by the }\end{array}$ & \multicolumn{4}{|l|}{1.303} \\
\hline
\end{tabular}

Table 10. Impact of row spacing and nitrogen $(\mathrm{N})$ on fruit yield (tons ha ${ }^{-1}$ ) of tomato

\begin{tabular}{c|ccc|c}
\hline \multirow{2}{*}{$\mathbf{N}\left(\mathbf{k g ~ h a}^{-1}\right)$} & \multicolumn{3}{|c|}{ Row spacing (cm) } & \multirow{2}{*}{ Mean } \\
\cline { 2 - 4 } & 60 & 90 & 120 & $23.94 \mathrm{c}$ \\
0 & 22.67 & 26.00 & 23.17 & $25.89 \mathrm{~b}$ \\
100 & 25.67 & 27.33 & 24.67 & $28.33 \mathrm{a}$ \\
140 & 27.00 & 30.33 & 27.67 & $26.56 \mathrm{ab}$ \\
\hline \multirow{2}{*}{ Mean } & 26.50 & 28.17 & 25.00 & \\
\hline LSD for Row spacing & $25.46 \mathrm{~b}$ & $27.96 \mathrm{a}$ & $25.13 \mathrm{~b}$ & \\
LSD for nitrogen & 2.244 & & & \\
\hline
\end{tabular}

Means followed by the same letter(s) do not differ significantly from one another at $5 \%$ probability level, using LSD test.

\section{Conclusion}

During the study it was observed that plant density and nitrogen levels had significant effect on growth and yield of tomato crop under walk-in polythene tunnel condition. In case of planting density, the $90 \mathrm{~cm}$ row spacing showed best results for most of the studied parameters including tomato yield followed by $120 \mathrm{~cm}$ row spacing. While $100 \mathrm{~kg} \mathrm{~N} \mathrm{ha}^{-1}$ gave best results for most of the studied parameters including tomato yield. Best results were observed regarding growth and yield parameters of tomato cv Sahil with the application of $100 \mathrm{~kg} \mathrm{~N} \mathrm{ha}^{-1}$ and $90 \mathrm{~cm}$ row spacing under walk-in polythene tunnel condition and hence recommended for better 
growth and high yield of tomato in the off season (winter season) at Malakand valley.

\section{Authors' contributions}

Conceived and designed the experiments: A Rab, Performed the experiments: A Rashid, H Mohammad, J Ali, M Shahab \& A Jamal, Analyzed the data: A Rashid \& A Rehman, Contributed reagents /materials/ analysis tools: J Ali \& M Ali, Wrote the paper: A Rashid.

\section{References}

1. Gould WA (1983). Tomato production, processing and quality evaluation. Avi Pub Co Westport Conn Pp 445.

2. Haghighi K \& Hancock JF (1992). DNA restriction fragment length variability in the genomes of highbush blueberry. Hort Science 27:44-47.

3. Bose TK \& Som MG. 1986. Vegetable crops India, Mitra, B. Naya Prokash, Bidhansanani, Calcutta. 70006, India. Pp.293-342.

4. Malik M (1994). Horti. (Ist Edition) National Book Foundation 508-509.

5. Fraser L \& Gester H (1991). The potential role of lycopene for human health. Journal of American Cell Nutrition 16:102-126.

6. Khachik F, Beecher GR \& Smith JC (1995). Lactein, Lycopene and their oxidative metabolites in chemo preservation of cancer. $J$ Cell Biochem Supply 22: 109-126.

7. Pandey RP, Solanki PN, Saraf RK \& Parihar MS (1996). Effect of Nitrogen and Phosphorus on growth and yield of tomato varieties. Punjab Vege Grower 31: 1-5.

8. Mehla CP, Srivastava VK, Jage S.Mangat R,Singh J \& Ram M(2000). Response of tomato varities to $\mathrm{N}$ and $\mathrm{P}$ fertilization and spacing. Ind J Agri Res 34(3): 182-184.

9. Sharma KC, Singh AK\&Sharma SK. (1999). Studies on Nitrogen and Phosphorus requirement of tomato hybrids. Annals Agri Res 20 (4): 339-402.

10. Haydar AM, Mandal A, Hannan MM, Karim R, Razvy MA, Roy UK \& Salahin M (2007). Studies on genetic variability and interrelationship among the different traits in tomato (Lycopersicum esculentum Mill.). Middle-East JSci Res 2(3-4): 139142.

11. Saeed A, Khan AA, Din I, Saeed N \&Alam MA (2008). Effects of $\mathrm{NaCl}$ on different yield components of tomato (Lycoperesicum esculentum Mill). Pak J Agri Sci 45(3): 29-35.

12. Kamruzzashan $\mathrm{M}$, Hossion $\mathrm{M}$, Islam $\mathrm{R}$ \&Alam MA (2000). Variability and correlation studies in tomato (Lycopersicum esculentum Mill.). Bangladesh J Genet Biotech 1(1): 21-26.

13. Hidaytullah $S$, Jatoi $A$, Ghafoor A \& Mahmood T (2008). Path coefficient analysis of yield components in tomato (Lycopersicum esculentum). Pak J Bot 40(2): 627-635.

14. Aggrey, Turuwork WA \& Tadelle A (1985). Review of Tomato Research in Ethiopia and Proposal for future Research and Development direction. In: GodfreySam-Aggrey and Bereke Tsehi (eds.). Proceedings of the First Ethiopian Horticultural Workshop. Pp236-249.

15. Wells OS \&Loy JB (1993). Row covers and high tunnels enhance crop production in the northeastern United States Hort Tech 3(1): 92-95

16. Wells OS \& Loy JB (1986). The current status of row cover use in the United States Proc Nat Agr Plastics Conf 19: 4-9.

17. Mawardi M \& Stewart K (1993). Effects of mini-tunnels and thermal tubes on soil and air temperatures. Proc Nat Agr Plastics Conf 24:31-42.

18. Steel RGD \&Torrie JH (1997). Analysis of covariance, In: Principles and procedures of statistics: a biometrical Approach, McGraw-Hill New York pp. 401-437

19. Rajagopal V \& Rao IM (1974). Changes in the endogenous level of auxins and gibberellins in the shoot apices of nitrogen deficient tomato plants. Aus J Bot 22(5): 429-435.

20. Gaffer MA \& Razzaque AHM (1983). Response of mustard to different levels of $\mathrm{N}, \mathrm{P}, \mathrm{K}$ fertilizers under two methods of seeding. Bangladesh Association for the 
Advancement of Sci Dhaka In: Proceeding 8th Bang Sci Conference BAAS, Dhaka, Bangladesh.

21. Medhi RP, Singh B \& Parthasarathy VS (1990). Effect of N, P and K on chillies. Prog Horti 22(1-4): 173-175.

22. Prabhakar M \& Naik LB (1997). Effect of supplemental irrigation and nitrogen fertilization on growth, yield, nitrogen uptake and water use efficiency of green chilli. Annals Agri Res 18(1): 34-39.

23. Shukla V, Srinivas K \& Prabhakar BS (1987). Response of bell pepper to nitrogen phosphorus and potassium fertilization. Ind J Hort 44(1/2): 81-84.

24. Olasantan FO (1991). Response of tomato and okra to nitrogen fertilizer in sole cropping and intercropping with cowpea. $J$ Hort Sci 6: 191-199.

25. Kagya A \& Norman JC (1977). The influence of nitrogen levels on local cultivars of eggplant. Acta Hort 2(53): 397-401.

26. Zekri M \& Obreza A (2003). Plant nutrients for citrus trees, Soil and Water Science Dept. Inst Food and Agric Sci Uni of Florida, fact sheet SL 200.

27. Haque ME, Paul AK \& Sarker JR (2011). Effect of Nitrogen and Boron on the Growth and Yield of Tomato (Lycopersicum esculentum L.). Intern $J$ Bio-resource Stress Manag 2(3): 277-282.

28. Law-Ogbomo KE \& Egharevba RKA (2009). Effects of planting density and NPK fertilizer application on yield and yield components of tomato (Lycospersicon esculentum L.) in forest location. world J Agric Sci 5(2): 152-158.

29. SainjuM, Dris R \& Singh B (2003). Mineral nutrition of tomato. Food Agric Environ 1(2): 176-183.

30. Banerjee MK, Balyan DS, Kalloo G, Azad S, Saini PS \&Singh A (1997). Effect of nitrogen fertilization and planting pattern of fruit yield of tomato cv. Hisar Lalima (Sel-18). Crop Res 14(3): 441-446.

31. Kirimi JK, Itulya FM \&Mwaja VN (2011).Effects of nitrogen and spacing on fruit yield of tomato. Afr J HortSci 5:5060.

32. Subramanian KS, Selvaraj KV, Selvakuman G \& Shanmugasundaram VS (1993). Influence of moisture regimes and nitrogen on growth and yield of brinjal (Solanum melongena L.) South Ind Hort 41(1): 16-21.

33. Dod VN, Joshi AT, Kale PB \& Kurlwal J (1983). Effect of different levels of nitrogen in split doses on yield and quality of red ripe chillies (Capsicum annuum L.) cv. G-3. Proceedings of National Seminar on Production Technology of Tomato and Chillies, Tamil Nadu Agric Uni Coimbatore

34. Ali SMR (1995). Effect of Plant Population Density on Tomato. ARC Training Report pp 1-3.

35. Balemi $\mathrm{T}$ (2007). Response of tomato cultivars differing in growth habit to nitrogen and phosphorus fertilizers and spacing on vertisol in Ethiopia. Acta Agric Slovenica 91(1): $438-119$.

36. Jia LW (1992). Plant Density Effect on Different Types of Tomato. ARC Training Report Pp 1-5

37. Rashid MDA (1993). Effect of Fertilizer Rates and Time of Application on Yield of Tomato. ARC Training Report Pp 1-3.

38. Sainju UM, Singh BP \&Whitehead WF (2001). Comparison of the effects of cover crops and nitrogen fertilization on tomato yield, root growth, and soil properties. Sci Hort 91: 201-214.

39. Badr MA \& El-Yazied AA (2007). Effect of fertigation frequency from subsurface drip irrigation on tomato yield grown on sandy soil. Aust J Basic Applied Sci 1(3): 279-285. 